\title{
(e)Portfolio: A history
}

\section{Orna Farrell \\ LaTrobe University}

\begin{abstract}
This paper traces the evolution of the concept of portfolio from the Renaissance to the present day. Over time the meaning of portfolio evolved from its origins as a case for holding loose papers to other contexts such as finance, government and education. Portfolios evolved from paper to electronic, from local network to the world wide web. The decade from 2000-2010 was a period when technology became part of mainstream society and educational technology become part of mainstream higher education, and portfolios became a ubiquitous assessment. From 2010-2020, a shift towards an emphasis on pedagogy and the student learning experience occurred in eportfolio research and practice. The history of (e)portfolio in higher education shows that the higher education system will continue to gradually evolve, incorporating concepts, technology and approaches that are compatible rather than transformative.
\end{abstract}

Keywords: portfolio; eportfolio; assessment; history of Edtech

\section{Introduction}

This paper presents a synopsis of a larger research project exploring the history of (e)portfolio in higher education (Farrell, 2020). The paper examines how portfolios have changed from a folder containing an artist's showcase of work to a higher education assessment. Further, it considers how technology has shaped and influence the purpose, use and engagement with electronic portfolios in the late twentieth and early twenty first centuries. There is a dearth of literature on the history of portfolio in higher education- electronic or paper based, with the exception of nominal contextual paragraphs in journal articles such as Lorenzo and Ittelson (2005) and Bryant and Chittum (2013) and a short background chapter in Lam's (2018) book about portfolio assessment. Very little consideration has been given to the theoretical, pedagogical, technological and educational origins of portfolio nor how they have evolved and changed over time. This is indicative of a general pattern in the education technology literature which Weller (2018, p. 34) describes as "amid this breathless attempt to keep abreast of new developments, the edtech field is remarkably poor at recording its own history or reflecting critically on its development".

\section{Methodology}

The methodology of this article follows a historical analysis approach drawing on primary documentary sources and secondary literature sources (Tosh, 2010). The literature review follows a hybrid approach incorporating aspects of traditional, systematic and historical approaches to research. The analysis follows a chronological narrative bounded by the time period 1400 to 2020 , and structured into four time periods. The study is guided by the following research question:

How has the concept of portfolio in higher education evolved over time?

In the literature, there are many related terms for portfolio, therefore the following search terms were adopted for this study, see table 1 .

Table 1: Search Terms

\begin{tabular}{|l|l|l|l|l|}
\hline Electronic portfolio & Virtual portfolio & Web portfolio & E-folio & E-portfolio \\
\hline $\begin{array}{l}\text { Personal learning } \\
\text { environment }\end{array}$ & Webfolio & Portfolio & Eportfolio & ePortfolio \\
\hline Digital portfolio & Learning portfolio & Teaching portfolio & Portfolio assessment & \\
\hline
\end{tabular}


The databases used to conduct the literature search were: Proquest, British Education Index, Education research complete, Sage journals, Scopus, JSTOR, ERIC, Google Scholar, and The PEARL eportfolio database http://eportfolio.aacu.org/. As not all relevant results were necessarily picked up by electronic databases, pearl growing and manual searching of key journals such as the International Journal of Eportfolio were also employed (EPPI-Centre, 2010). Each study was assessed by reading the title and abstract for relevance to the inclusion criteria and to the guiding question for the literature review, see table 2 below.

Table 2: inclusion and exclusion criteria

\begin{tabular}{|l|l|}
\hline Inclusion criteria & Exclusion criteria \\
\hline $\begin{array}{l}\text { Primary sources: document, image, first } \\
\text { person account }\end{array}$ & Not in English or translated \\
\hline Peer reviewed-journal article & Full text unavailable \\
\hline Available full-text & Secondary sources-not peer reviewed \\
\hline Academic texts & After 1990 other education contexts \\
\hline After 1970, higher education focused & \\
\hline
\end{tabular}

\section{Origins and early usage}

The portfolio concept has its origins in 15th century Italy, where artists and architects collated examples of their work (Dorn, Sabol, \& Madeja, 2013). The etymology of the word portfolio comes from the Italian word portafoglio, meaning a case or folder for carrying loose papers or pictures (Oxford English Dictionary 2006; Lam 2018). An early example of portfolios in use was in Montepulciano in 1440, the architect Michellozzo submitted a portfolio of designs for a new hospital to the city for approval (Goldthwaite, 1980). An interesting example of a renaissance portfolio are the notebooks of Leonardo da Vinci, which were loose folios bound together after his death (Dorn, Sabol, \& Madeja 2013). Da Vinci kept notes and drawings of his studies, ideas and inventions on loose folios of which over 7,000 pages still exist, see figure 1 below which shows a folio from one of Leonardo's notebooks called the Codex Arundel were produced around 1500.

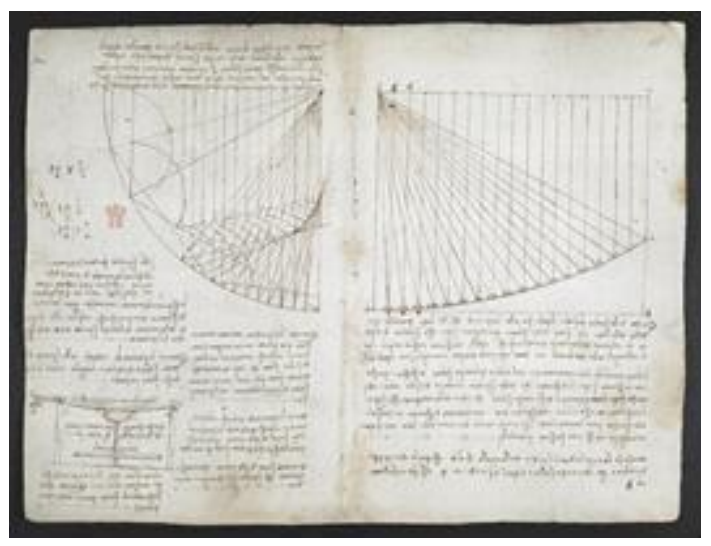

Figure 1. Folio from Da Vinci Codex Arundel. Reproduced with permission from the British Library

During the 18th and 19th centuries portfolios became more commonplace, particularly in the context of art (Oxford English Dictionary, 2006). This is evident in both written and visual sources from the period. For example, French fashion plates from 1800-1830 produced in the fashion magazine Le Journal des Dames et des Modes, demonstrate how the portfolio had become a mainstream fashion accessory, see Figure 2 (University of Washington Libraries 2020). 


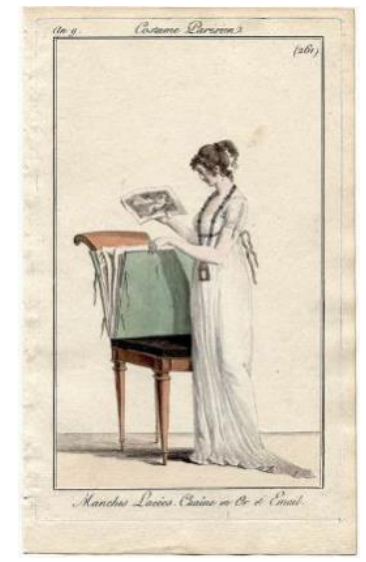

Figure 2. French fashion plate. Reproduced with permission Bibliothèque des Arts Décoratifs.

\section{The 70s and 80s}

Portfolios crossed over from art to higher education during the early 1970s. Early adopters of portfolio assessment were the disciplines of education and English. English writing composition educators such as Ford and Larkin (1978) were early adopters of portfolio assessment, they reported that portfolio assessment was introduced in their general education English writing classes at Brigham Young University in 1970. The use and definition of portfolio assessment described by Ford and Larkin is still quite similar to its original artistic purpose, "the portfolio system entails the disinterested judging of each student's work, collected, like the best representative work of an artist, into a "portfolio" (in this case a large manila envelope), which is read by at least one teacher besides the one from whom the student is taking the class" (Ford \& Larkin, 1978, p.951). Portfolios were introduced into teacher education in the United States from 1986-1990 through the work of Lee Shulman on the Stanford Teacher Assessment Project (Haertel, 1991). Over the course of the 1980s, the nature of portfolio usage and purpose evolved from the original artistic conception as a method of showcasing a selection of best work for a specific audience to an educational approach to document student progress, process, competency and achievement over time. Two distinct philosophical approaches were evident in this period: a constructivist and a competency based (Habib \& Wittek 2007).

\section{The 1990s}

By the start of the 1990s, there was a "portfolio explosion" in higher education, portfolio assessment expanded from the disciplines of education and English into nursing, engineering, medicine, and science (Elbow \& Belanoff 1997, p.21). The early conceptions of (e)portfolios envisaged digital versions of the paper based portfolios. The first electronic portfolios were created using computer intranets. For example, Wall and Peltier (1996) described using a university intranet with folders based on Mac called Docex for their class electronic portfolio. One of the early adopters of (e)portfolios in education was Helen Barrett, her early work considered how to technically create and store a portfolio using CDs and video compression technology and the pedagogical conception of a working vs. formal portfolio (Barrett 1994). During the 1990s, portfolios evolved from paper to electronic, from local network to the world wide web. The affordance of technology to create electronic portfolios which were more accessible, contained multimedia and hypertext was viewed by some practitioners with enthusiasm but there was awareness that "working in the electronic medium, we are being shaped in ways no one fully understands" (Yancey, 1996). Further, the idea of a linked network of documents which in the present day is so commonplace was in 1996 perceived as a radical shift, "A portfolio is a hypertext. It comprises a number of text or artefact spaces created and arranged by the author. In education, the author is usually the student. The student creates a network among the artefacts" (Purves, 1996).

\section{The 2000s}

The decade from 2000-2010 was a period when technology became part of society and the higher education system. Universities and their staff and students adopted elearning, virtual learning environments (VLE), virtual worlds, video, blogs, open education resources (OER), social media and eportfolio into the higher education ecosystem (Weller, 2018). During the 2000s, there was a proliferation of eportfolio platforms. By 2005, there 
were home-grown web based eportfolio platforms such as the Denver University Portfolio Community system, open-source platforms such as Sakai and commercial packages such as Taskstream and Chalk \& Wire (Lorenzo and Ittleson 2005; Batson 2002). Eportfolio entered the mainstream higher education discourse and were received with hyperbolic enthusiasm; "eportfolios might be the biggest thing in technology innovation on campus. Electronic portfolios have a greater potential to alter higher education at its very core than any other technology application we've known thus far" (Batson 2002). As eportfolios became more widespread, educators began to define, theorise, and research eportfolio in the higher education context. One of the most common themes in the eportfolio theoretical literature from this decade was the centrality of reflection to learning with an eportfolio (Brandes \& Boskic, 2008; Yancey, 2009). Several pedagogical models for learning with an eportfolio were developed during this decade:

- Abrami \& Barrett (2005) three purposes of eportfolio: process, showcase and assessment

- Zubizarreta's (2009) learning portfolio model with three components: reflection, documentation and collaboration

- Chen \& Penny Light's (2010) Folio Thinking approach

In higher education practice during the 2000 s, eportfolio were used for: summative assessment, developmental or formative assessment, and documenting placement experiences (Farrell, 2018). As the theory and practice of eportfolio developed, research did not keep pace. According to Wray (2007, p.50) "While theoretical support regarding the benefits of portfolios is strong, scant empirical support is available".

\section{Definitions}

As eportfolios became more widespread, educators began to articulate, theorise and develop the concept of electronic portfolio assessment in higher education. The four most commonly cited definitions of eportfolio by JISC (2008), Abrami and Barrett (2005), Lorenzo and Ittleson (2005) and Hartnell-Young (2007) permeate the literature on eportfolio, see Table 3 below.

\section{Table 3: Definitions of eportfolio: most commonly cited}

“An e-portfolio is a digitized collection of artefacts including demonstrations, resources, and accomplishments that
represent an individual, group, or institution. This collection can be comprised of text-based, graphic, or
multimedia elements archived on a Web site or on other electronic media such as a CD-ROM or DVD. An e-
portfolio is more than a simple collection-it can also serve as an administrative tool to manage and organize work
created with different applications and to control who can see the work. E-portfolios encourage personal reflection
and often involve the exchange of ideas and feedback" (Lorenzo and Ittleson 2005).
"An eportfolio is a digital container capable of storing visual and auditory content including text, images, video
and sound. Eportfolio may also be software tools not only because they organize content but also because they are
designed to support a variety of pedagogical processes and assessment purposes" (Abrami and Barrett 2005).
"An eportfolio is the product, created by the learner, a collection of digital artefacts articulating experiences,
achievements and learning. Behind any product, or presentation, lie rich and complex processes of planning,
synthesising, sharing, discussing, reflecting, giving, receiving and responding to feedback" (JISC 2008).
"Broadly, the product eportfolio is a purposeful selection of items (evidence) chosen at a point in time from a
repository or archive, with a particular audience in mind. The processes that are required to create eportfolio - for
any purpose - include capturing and ongoing storage of material, selection, reflection and presentation" (Hartnell-
Young 2007).

\section{The 2010s}

In the final decade, eportfolio researchers increasingly focused on gathering empirical data on the impact of eportfolio on student learning. This was in response to the dearth of empirical research on eportfolio highlighted by Bryant and Chittum (2013) in their systematic review of eportfolio research. The literature from this decade indicates that eportfolio based assessment enables students to integrate their learning and make connections between modules in an authentic and meaningful way (Buente et al., 2015; Eynon and Gambino 2017; Morreale 
et al., 2017).

In higher education practice, the nature of eportfolio use broadened during this decade from a medium for assessment to a vehicle for documenting student non formal learning such as study abroad experiences, to support academic advising and to collect evidence of graduate attributes (Farrell, 2018). One of the emerging uses of eportfolio is to document the whole learning career of a student, including the co-curricular elements such as volunteering, involvement in student societies, sports, mentoring and study abroad experiences (Eynon and Gambino, 2017). For example, Business students at Dublin City University (DCU) are documenting their Erasmus study abroad informal learning experiences through eportfolio practice (O'Reilly and Donaldson, 2018). Specifically, an eportfolio program has been designed to facilitate students studying abroad to reflect on their overseas experiences and integrate it into a wider intercultural framework. Emerging areas of theory, research and practice in eportfolio at the end of this decade are experiments with block chain, badges, eportfolio and MOOCs, and concerns about data ethics, ownership, and GDPR.

\section{Conclusions}

Over time the portfolio has evolved from its origins as a case for holding loose papers to other contexts such as finance, government and education. Portfolios evolved from paper to electronic, from local network to the world wide web. The history of portfolio in higher education shows that the higher education system will continue to gradually evolve, incorporating concepts, technology and approaches that are compatible rather than transformative. However, the pivot online due to the Covid-19 pandemic may interrupt this gradual evolution of the higher education system. Alternative assessment approaches such as eportfolio, blogs, online presentations, wikis, podcasts, and videos became mainstream in the blink of an eye. Will this shift be permanent?

\section{References}

Abrami, P.C, Barrett, H. 2005. Directions for Research and Development on Electronic Portfolios. Canadian Journal of Learning and Technology, 31(3).

Barrett, H. 1994. Technology-Supported Portfolio Assessment, The Computing Teacher. Available from https://electronicportfolios.org/

Batson, T. (2002). The Electronic Portfolio Boom: What's it All About? Syllabus: Technology for Higher Education.

Brandes, G.M., Boskic, N. (2008). Eportfolio: From Description to Analysis. International Review of Research in Open and Distance Learning. 9(2),1-17.

Bryant, L. and Chittum, J. (2013). ePortfolio effectiveness: a(n ill-fated) search for empirical support, International Journal of ePortfolio, 3(2), pp. 189-198.

Buente, W., Winter, J.S., Kramer, H., Dalisay, F., Hill, Y.Z. and Buskirk, P.A. 2015. Program based assessment of capstone eportfolios for a communication BA curriculum, International Journal of ePortfolio, 5(2), pp.169--179.

Chen, H.L. and Penny Light, T. (2010). Electronic portfolios and student success: Effectiveness, efficiency, and learning. Washington: AACU.

Dorn, C.M., Sabol, S.S., Madeja, F. (2013). Assessing Expressive Learning. London: Routledge. EPPI. (2010). Methods for Conducting Systematic Reviews. Retrieved from https://eppi.ioe.ac.uk

Elbow, P., \& Belanoff, P. (1997). Reflections on an explosion: Portfolios in the 90s and beyond. In K. Yancey \& I. Weiser (Eds.), Situating portfolios: Four perspectives (pp. 21-33). Logan, UT: Utah State UPress.

Eynon, B., Gambino, L. (2017). High Impact ePortfolio Practice. Sterling: Stylus.

Farrell, O. (2018). Failure to Launch: The unfulfilled promise of ePortfolios in Irish higher education: An opinion piece. DBS Business Review, 2. doi: 10.22375/dbr.v2i0.30

Farrell, O. (2020). From portafoglio to eportfolio: the evolution of portfolio in higher education. Journal of Interactive Media in Education, 2020(1), p.19. DOI: http://doi.org/10.5334/jime.574..

Ford, J., \& Larkin, G. (1978). The Portfolio System: An End to Backsliding Writing Standards. College English, 39(8), 950-955. doi:10.2307/376206

Habib, L. \& Wittek, L. (2007). The Portfolio as Artifact and Actor. Mind, Culture, and Activity, 14(4): 266-282. doi:10.1080/10749030701623763

Haertel, E. (1991). New Forms of Teacher Assessment. Review of Research in Education, 17, 3-29. doi: $10.2307 / 1167328$

Lam R. (2018). Background of Portfolio Assessment. In: Portfolio Assessment for the Teaching and 
Learning of Writing. Springer Briefs in Education. Springer, Singapore.

Lorenzo, G., Ittelson, J. (2005). An Overview of E-Portfolios. Educause review.

https://www.educause.edu/

Morreale, C., Van Zile-Tamsen, C., Emerson, C.A. and Herzog, M. (2017). Thinking skills by design: a capstone eportfolio to promote reflection, critical thinking and curriculum integration', International Journal of Eportfolio, 7(1)13-28.

Purves, A., (1996). Electronic portfolios. Computers and Composition, 1 (2): 135-146. DOI: https://doi.org/10.1016/S8755-4615(96)90004-3

O'Reilly, N., Donaldson, L., (2018).Thank you, Dear Diary, for giving me this Space: The Use of eportfolios to develop reflective practice during a Study Abroad year. EdTech 2018, Carlow, 1st June. Oxford English Dictionary. (2006). Portfolio. Available from https://www.oed.com/

Tosh, J. (2010). The Pursuit of History. Edinburgh: Pearson. University of Washington Libraries (2020). French Fashion Plate Collection. https://content.lib.washington.edu/costumehistweb/index.html

Wall, B. C., \& Peltier, R. F. (1996). "Going public" with electronic portfolios: Audience, community, and the terms of student ownership. Computers and Composition, 13(2), 207-217. doi:10.1016/S8755- 4615(96)90010-9

Weller, M. (2018). Twenty Years of Edtech, Educause Review, 53(4), 34-48. Available from https://www.educause.edu/

Yancey, K., 1996. Portfolio, electronic, and the links between. Computers and Composition, 13 (2): 129-133. doi: https://doi.org/10.1016/S8755-4615(96)90003-1

Yancey, K. (2009). Reflection and Electronic Portfolios. In Cambridge, D., Cambridge, B., Yancey, K., (Eds) Electronic Portfolios 2.0. (pp. 5-17) Sterling: Stylus.

Zubizarreta, J. (2009). The Learning Portfolio: Reflective Practice for Improving Student Learning. (2nd ed.) San Francisco: Jossey-Bass.

Farrell, O. (2020). (e)Portfolio: a history. In S. Gregory, S. Warburton, \& M. Parkes (Eds.), ASCILITE's First Virtual Conference. Proceedings ASCILITE 2020 in Armidale (pp. 289-294). https://doi.org/10.14742/ascilite2020.0108

Note: All published papers are refereed, having undergone a double-blind peer-review process.

The author(s) assign a Creative Commons by attribution licence enabling others to distribute, remix, tweak, and build upon their work, even commercially, as long as credit is given to the author(s) for the original creation.

(C) Farrell, O. 2020 